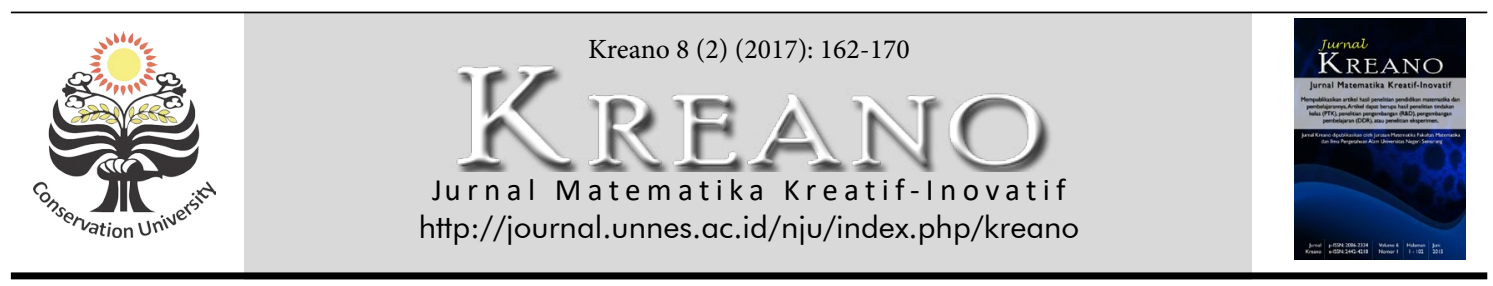

\title{
Profil Penalaran Proporsional Siswa SMP dalam Memecahkan Masalah Matematika Berdasarkan Gaya Kognitif Sistematis dan Intuitif
}

\author{
Akhmad Faisal Hidayat' ${ }^{1}$ Siti Maghfirotun Amin², Yusuf Fuad² \\ 'Program Studi S2 Pendidikan Matematika Universitas Negeri Surabaya \\ Email: af.iechal@gmail.com ${ }^{1}$
}

DOI: http://dx.doi.org/10.15294/kreano.v8i2.9635

Received : August 2017; Accepted: June 2017; Published: December 2017

\begin{abstract}
Abstrak
Penelitian ini merupakan penelitian deskriptif dengan pendekatan kualitatif. Tujuan penelitian ini adalah mendeskripsikan profil penalaran proporsional siswa SMP dalam memecahkan masalah matematika berdasarkan gaya kognitif sistematis dan intuitif. Penelitian ini dilakukan di kelas IX SMP AI-Muslim Sidoarjo pada tahun ajaran 2016/2017. Subjek penelitian ini adalah seorang siswa bergaya kognitif sistematis dan seorang siswa bergaya kognitif sistematis. Alat pengumpul data berupa Tes Gaya Kognitif (TGK), Tugas Pemecahan Masalah (TPM), Pedoman wawancara, dan alat rekam audio visual. Data penelitian diperoleh dari pemberian tugas pemecahan masalah dan wawancara sebanyak dua kali. Wawancara dilakukan untuk mengungkapkan profil penalaran proporsional dalam memecahkan masalah matematika terkait materi perbandingan. Keabsahan data diuji dengan triangulasi waktu. Hasil penelitian menunjukkan kedua subjek gagal membedakan masalah proporsional dan bukan proporsional pada tahap memahami masalah. Pada tahap menyusun rencana, Siswa bergaya kognitif sistematis mengelompokkan bagian-bagian yang sebanding untuk membuat persamaan. Sedangkan siswa bergaya kognitif intuitif membandingkan luas lahan pertama dan kedua, kemudian menyederhanakan perbandingannya. Pada tahap melaksanakan rencana, siswa bergaya kognitif sistematis menggunakan strategi cross product algorithm untuk menemukan solusi. Sedangkan siswa bergaya kognitif intuitif menggunakan strategi build-up method dan factor of change untuk menemukan solusi. Pada tahap memeriksa kembali, Siswa bergaya konitif sistematis dan intuitif mengecek solusi yang mereka peroleh dengan mensubtitusi masing-masing solusi ke persamaan, kemudian melihat nilai perbandingan yang dihasilkan. Jawaban benar jika nilai perbandingan dalam persaamaan tersebut sama.
\end{abstract}

\begin{abstract}
This research uses descriptive qualitative approach. The purpose of this study was to describe proportional reasoning profile of junior high school student in mathematical problem solving based on systematic and intuitive cognitive style. This study was do ini class IX SMP Al-Muslim Sidoarjo in 2016/2017. One subject is systematic cognitive style and the other is intuitive cognitive style. The colect data instruments are TGK, TPM, interview guidence, and video recorder. Data were obtain from giving problem solving task and gave interview twice during the study. Interviews were do for exploration proportional reasoning profile of junior high school student in mathematical problem solving about proportional problems. The validity of the data is tested using time triangulation. The result of this research showed both of subjects failed to different the proportional problem and non-proportional problems on understanding step. On planning step, systematic student collected the same parts to make a equation. Intuitive student compared large of first field and second, and simplified it. On doing step, systematic student use cross product algorithm strategy to find solution. Intuitive student used build-up method and factor of change strategy to find solution. On overview step, systematic and intuitive student checking with substitution the solution in equation and look at the comparing values. If the comparing values are same, it means the subject got correct answer.
\end{abstract}

Keywords: proportional reasoning; problem solving; systematic; intuitive 


\section{PENDAHULUAN}

Bernalar dalam memecahkan masalah merupakan salah satu tujuan dalam pembelajaran matematika di sekolah. Permendikbud Nomor 58 tahun 2014 menyatakan bahwa matematika diajarkan dengan tujuan agar siswa memiliki kemampuan menggunakan penalaran, melakukan manipulasi matematika baik dalam penyederhanaan, maupun menganalisa komponen yang ada dalam pemecahan masalah, baik dalam konteks matematika maupun di luar matematika (Kemdikbud, 2014). Selain itu, penalaran juga digunakan dalam hal memahami masalah, membangun model matematika, menyelesaikan model dan menafsirkan solusi yang diperoleh, termasuk dalam rangka memecahkan masalah dalam kehidupan sehari-hari. Dengan kata lain melalui kegiatan bernalar, siswa dibiasakan untuk dapat berpikir logis, kritis, analitis, serta sistematis dalam menghadapi masalah, sehingga dapat memecahkannya dan menemukan solusi yang tepat dari permasalahan tersebut.

Terdapat beberapa jenis penalaran matematis, di antaranya penalaran probabilistik, penalaran korelasional, penalaran kombinatorial dan penalaran proporsional. Salah satu penalaran yang berperan penting dalam pembelajaran matematika adalah penalaran proporsional.

Penalaran proporsional pada dasarnya merupakan istilah yang tidak dapat didefinisikan dengan jelas (Lamon, 2012: 2; Lamon, 2007). Namun, Lamon (2007) mencoba memberikan gambaran bahwa penalaran proporsional ialah segala sesuatu yang berhubungan dengan rasio dan proporsi. Menurut Lesh (1988) penalaran proporsional adalah bentuk penalaran matematika yang melibatkan kovariasional dan beberapa perbandingan, serta kemampuan mental untuk menyimpan dan memproses beberapa bagian dari informasi. Walle (2013, p.357; Ben-Chaim, Keret, \& llany; 2012:32) menambahkan bahwa penalaran proporsional merupakan "a way of reasoning about multipilcative situation". Dengan kata lain, penalaran proporsional merupakan cara seseorang dalam bernalar pada situasi multiplikatif. Lebih jauh, Lamon (2007) mengkategorikan penalaran proporsional sebagai ke- mampuan memberi alasan untuk mendukung pernyataan yang dibuat mengenai hubungan secara structural antara 4 kuantitas (sebut a, b, c, d) dalam konteks secara simultan melibatkan kovarian dari kuantitas dan invarian dari rasio atau perkalian. Lamon (2007) juga menjelaskan kemampuan tersebut terdiri dari kemampuan membedakan hubungan perkalian antara dua kuantitas serta kemampuan untuk memperluas hubungan yang sama ke pasangan kuantitas lain. Penalaran proporsional ditekankan pada kemampuan memberikan alasan karena banyak siswa dapat memperoleh jawaban yang benar secara numerikal untuk masalah proporsi menggunakan prosedur algoritma, tetapi hal ini belum tentu berarti siswa secara tepat menggunakan penalaran proporsional (Frith \& Lloyd, 2016).

Menurut Lesh, Post, \& Behr (1988) semua orang yang menyelesaikan masalah yang melibatkan proprosi belum tentu menggunakan penalaran proporsional. Sehingga, penalaran proporsional merupakan salah satu jenis penalaran yang penting, karena terkait dengan konsep rasio dan proporsi. Pengetahuan mengenai rasio dan proporsi, membantu dalam menyelesaikan aktivitas berhitung dan pemecahan masalah terkait dengan skala, peluang, persen, rerata, trigonometri, kesebangunan, pengukuran, geometri bidang dan ruang serta aljabar (Dole, Clarke, Wright \& Hilton (2012, h.195). Melihat banyaknya cakupan materi yang mengaitkan antara konsep rasio dan proporsi dengan pemecahan masalah, maka dapat dikatakan bahwa penalaran proporsional memiliki peranan penting dalam aktivitas pemecahan masalah.

Mengamati penalaran proporsional siswa dalam memecahkan masalah merupakan hal penting untuk dilakukan dalam pembelajaran. Melalui pengamatan tersebut, guru dapat mengetahui apa saja yang masih dibutuhkan siswa dalam proses perkembangannya, sehingga dapat menciptakan pembelajaran yang lebih baik. Sebagaimana yang tertuang dalam prinsip matematika sekolah oleh NCTM (2000), "Effective mathematics teaching requires understanding what students know and need to learn and then challenging and supporting them to learn it well".

Pemecahan masalah merupakan akti- 
vitas mental yang terdiri dari berbagai keterampilan dan tindakan kognitif (Kirkley, 2003). Selain itu, melalui pemecahan masalah, siswa diarahkan agar dapat menerapkan dan mengadaptasi berbagai strategi dan pendekatan pemecahan masalah, memonitor serta melakukan refleksi terhadap proses pemecahan masalah, baik yang melibatkan masalah matematika maupun dalam konteks yang lain (NCTM, 2000). Ada beberapa tahap dalam pemecahan masalah, salah satu tahap yang lazim digunakan adalah tahap pemecahan masalah yang diungkapkan oleh Polya (kalau ada sumber). Polya (1973) membagi tahap pemecahan masalahnya kedalam empat tahap, yakni memahami masalah, membuat perencanaan, melaksanakan perencanaan dan memeriksa kembali.

Berdasarkan tahap pemecahan masalah Polya, dapat dikatakan bahwa kemampuan siswa dalam memecahkan masalah, bergantung pada kemampuannya dalam memahami serta menguraikan permasalahan yang dihadapi. Cara siswa dalam belajar serta memahami dan menguraikan masalah, sebagian besar bergantung pada hubungan yang terbentuk antara kepribadian dan kognisinya yang disebut sebagai gaya kognitif (Jena, 2014). Gaya kognitif merupakan cara seseorang dalam memperoleh dan memproses informasi dalam otaknya. Lebih lanjut, Martin (1998) menambahkan bahwa gaya kognitif seseorang dalam hal ini siswa, berpengaruh terhadap cara dia berpikir, belajar, memecahkan masalah, serta berinteraksi terhadap lingkungannya.

Terdapat beberapa tipe gaya kognitif, antara lain gaya kognitif Field DependentField Independent, Visualizer-Verbalizer, Reflektif-Impulsif, serta Sistematis-Intuitif. Diantara berbagai penggolongan gaya kognitif tersebut, sistematis-intuitif merupakan tipe gaya kognitif yang digolongkan berdasarkan cara mengevaluasi informasi dan memilih strategi dalam penyelesaian masalah (Keen, 1974). Kedua gaya kognitif tersebut berpengaruh terhadap aktivitas berpikir, cara memahami dan pengambilan keputusan (Martin, 1998).

Dalam penelitian ini, penalaran proporsional yang dimaksud adalah kemampuan menyatakan hubungan antar kuantitas yang melibatkan kovariasi dari kuantitas dan invarian dari rasio dalam konteks simultan dan kemampuan memperluas hubungan yang sama ke pasangan kuantitas lain, serta kemampuan menjelaskan alasan terkait hubungan antar kuantitas yang dibuat. Jadi, penalaran proporsional dalam penelitian ini meliputi tiga kemampuan yaitu (1) kemampuan menyatakan hubungan antar kuantitas yang melibatkan kovariasi dari kuantitas dan invarian dari rasio dalam konteks simultan, (2) kemampuan untuk memperluas hubungan yang sama ke pasangan kuantitas lain, dan (3) kemampuan menjelaskan alasan terkait hubungan antar kuantitas yang dibuat.

\section{METODE}

Penelitian ini merupakan penelitian deskriptif dengan pendekatan kualitatif. Penelitian ini bertujuan mendeskripsikan profil penalaran proporsional siswa SMP dalam memecahkan masalah matematika berdasarkan gaya kognitif sistematis dan intuitif. Pengumpulan data dilakukan dengan merekam secara audio visual ketika subjek mengerjakan TPM dan wawancara. Wawancara dilakukan untuk mengungkapkan penalaran proporsional siswa SMP dalam memecahkan masalah matematika berdasarkan gaya kognitif sistematis dan intuitif. Aktivitas dalam menganalisis data adalah kondensasi data, penyajian data, gambaran dan verifikasi kesimpulan.

Penelitian ini dilakukan di kelas IX SMP Al-Muslim Sidoarjo pada tahun ajaran 2016/2017. Subjek penelitian ini adalah seorang siswa bergaya kognitif sistematis dan seorang siswa bergaya kognitif sistematis. Kedua subjek tersebut dipilih berdasarkan hasil anlisis Tes Gaya Kognitif (TGK) dan kemampuan matematika yang ditunjukkan melalui hasil rerata UH dan UTS.

Instrumen pengumpulan data dalam penelitian ini adalah Tes Gaya Kognitif (TGK), Tugas Pemecahan Masalah (TPM), Pedoman wawancara, dan alat rekam audio visual. Data penelitian diperoleh dari pemberian tugas pemecahan masalah dan wawancara sebanyak dua kali. Wawancara dilakukan untuk mengungkapkan profil penalaran proporsional dalam memecahkan masalah matematika terkait materi perbandingan. Wawancara 
dilakukan berdasarkan tahap pemecahan masalah Polya dan karakteristik penalaran proporsional. Keabsahan data diuji dengan triangulasi waktu.

\section{HASIL DAN PEMBAHASAN}

\section{Hasil}

TGK tidak diberikan pada seluruh siswa kelas IX. TGK ini hanya diberikan pada siswa kelas IX-C yang terdiri atas 25 siswa karena berdasarkan hasil observasi peneliti, kelas IX-C memiliki kemampuan matematika di atas rata-rata dibanding kelas IX lain. Berikut pemilihan subjek berdasarkan hasil analisis skor TGK dan kemampuan matematika siswa yang didasarkan pada nilai rerata UH dan UTS.

Tabel 1. Pemilihan Subjek Berdasarkan Hasil Analisis Skor TGK dan Kemampuan Matematika

\begin{tabular}{|c|c|c|c|c|c|}
\hline \multirow{3}{*}{$\begin{array}{l}\text { Inisial } \\
\text { Siswa }\end{array}$} & \multirow{3}{*}{$\begin{array}{c}\text { Skor } \\
\text { Sistematis }\end{array}$} & \multicolumn{3}{|l|}{ Siswa } & \multirow{3}{*}{ KET } \\
\hline & & \multirow{2}{*}{$\begin{array}{l}\text { Skor } \\
\text { Intuitif }\end{array}$} & \multicolumn{2}{|c|}{$\begin{array}{l}\text { Kemampuan } \\
\text { Matematika }\end{array}$} & \\
\hline & & & $\begin{array}{c}\text { Rerata } \\
\text { UH }\end{array}$ & UTS & \\
\hline AN & 78 & 85 & 74 & 76 & \\
\hline AR & 52 & 63 & 83 & 84 & \\
\hline DA & 89 & 75 & 80 & 84 & \\
\hline FR & 34 & 50 & 82 & 88 & \\
\hline $\mathrm{HF}$ & 63 & 71 & 77 & 80 & \\
\hline IK & 49 & 66 & 81 & 76 & \\
\hline IM & 52 & 41 & 78 & 80 & \\
\hline LAP & 75 & 64 & 85 & 84 & \\
\hline LN & 80 & 73 & 80 & 84 & \\
\hline LRD & 87 & 49 & 89 & 92 & $\mathrm{~S}_{1}$ \\
\hline MA & 71 & 48 & 75 & 80 & \\
\hline MD & 68 & 51 & 86 & 84 & \\
\hline MER & 77 & 62 & 79 & 76 & \\
\hline $\mathrm{ML}$ & 82 & 76 & 92 & 88 & \\
\hline MM & 53 & 71 & 81 & 84 & \\
\hline MRD & 47 & 42 & 77 & 80 & \\
\hline MRZ & 73 & 84 & 79 & 80 & \\
\hline MS & 79 & 65 & 84 & 84 & \\
\hline RI & 64 & 75 & 85 & 80 & \\
\hline RRP & 45 & 85 & 91 & 88 & $\mathrm{~S} 2$ \\
\hline $\mathrm{SBH}$ & 48 & 70 & 81 & 84 & \\
\hline SL & 57 & 41 & 78 & 76 & \\
\hline $\mathrm{TL}$ & 62 & 83 & 83 & 80 & \\
\hline YM & 41 & 50 & 80 & 84 & \\
\hline ZD & 55 & 73 & 86 & 80 & \\
\hline
\end{tabular}

\section{Penalaran S1 dalam Memecahkan Masalah} Matematika

Berdasarkan masalah yang diberikan, S1 mampu mengetahui dengan baik informasi yang diketahui dari masalah yang diberikan. Namun S1 melakukan kesalahan dalam menentukan masalah proporsional dan non-proporsional. Berikut penyelesaian masalah yang ditulis oleh $\mathrm{S} 1$.

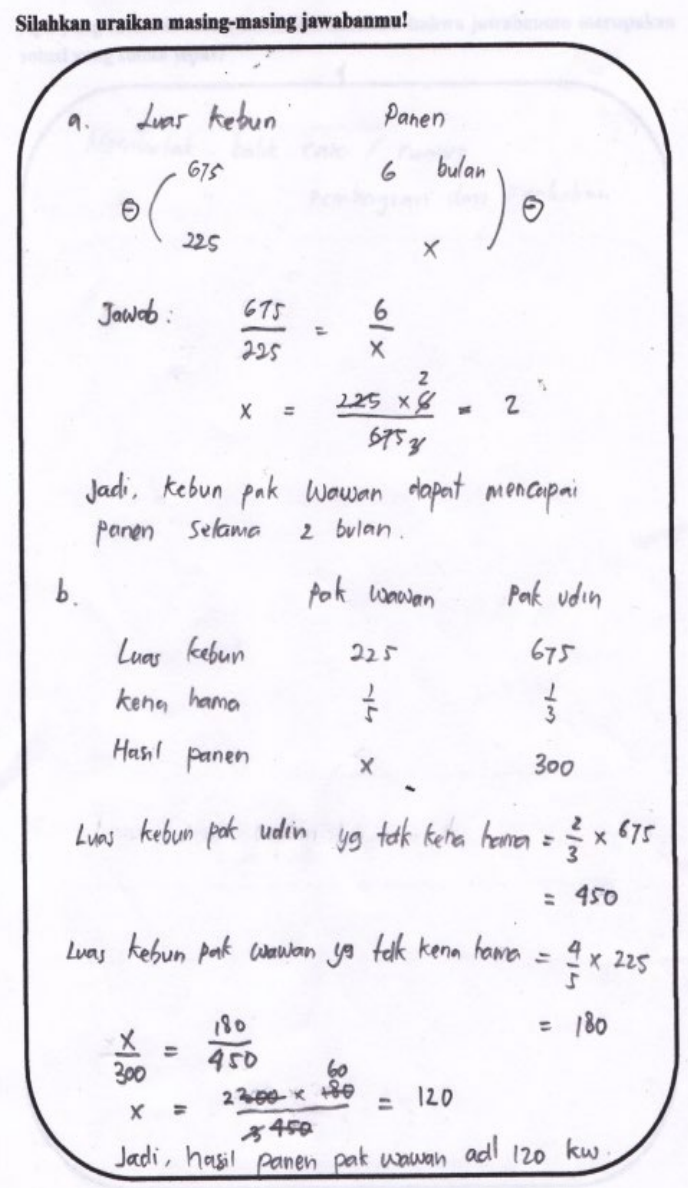

Gambar 1. Penyelesaian Masalah yang Ditulis S1

Berdasarkan gambar di atas terlihat $\mathrm{S}_{1}$ mengetahui dengan baik informasi yang diberikan pada soal dengan menuliskan kembali semua bagian-bagian yang diketahui dari soal yang diberikan. Namun Si melakukan kesalahan dalam menentukan masalah matematika 1a sebagai masalah proporsional. S1 memahami bahwa menghitung lama panen dan hasil panen, keduanya merupakan masalah proporsional karena bergantung pada luas lahan.

Untuk menggali lebih dalam profil 
penalaran S1 dalam memecahkan masalah yang diberikan, berkut cuplikan wawancara dengan S1.

P: Menurut kamu, soal seperti ini berkaitan dengan materiapa?

S1: Materi perbandingan kak.

$P$ :Apakah kedua pertanyaan dari soal ini berkaitan dengan materi perbandingan?

S1 : lya kak.

$P$ : Apa alasanmu mengatakan demikian?

S1: Karena diketahui luas kebun dan ditanyakan lama panen dan hasil panennya. Padahal lama panen dan hasil panen bergantung pada luas kebun.

$P$ : Mengapa kamu bisa mengatakan kalau lama panen dan hasil panen bergantung dengan luas kebun?

S1: Karena semakin luas kebun maka semakin lama waktu panen dan semakin banyak hasil panen.

\section{Penalaran S2 dalam Memecahkan Masalah Matematika}

Berdasarkan masalah yang diberikan, S2 juga mampu mengetahui dengan baik informasi yang diketahui dari masalah yang diberikan. Namun $S_{2}$ juga melakukan kesalahan yang dilakukan oleh $\mathrm{S} 1$ yaitu dalam menentukan masalah proporsional dan non-proporsional. Berikut penyelesaian masalah yang ditulis oleh S2.

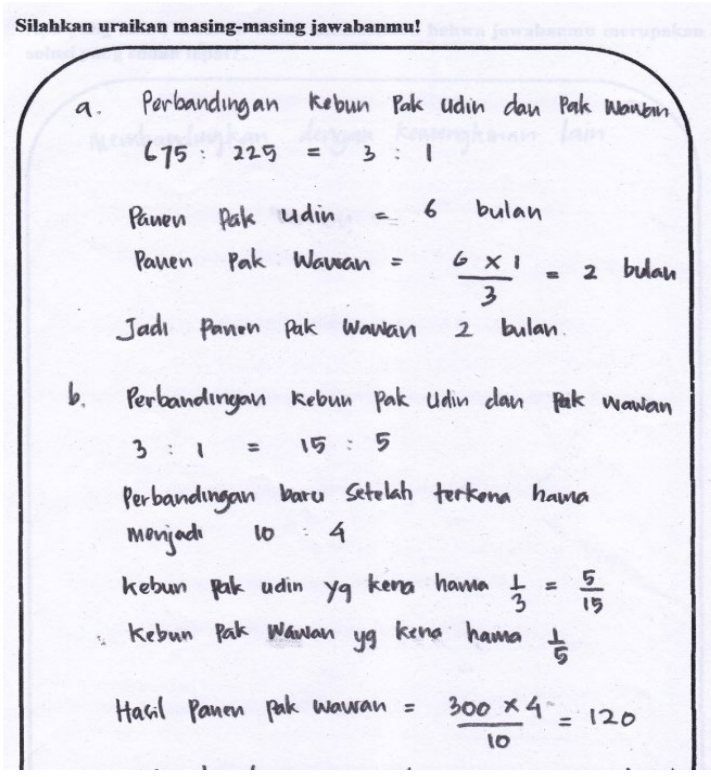

Gambar 2. Penyelesaian Masalah yang Ditulis S2
Berdasarkan gambar di atas terlihat bahwa S2 mengetahui dengan baik informasi yang diberikan pada soal dan masalah yang akan diselesaikan. S2 juga mengungkapkan bahwa soal yang diberikan merupakan masalah proporsional karena berkaitan dengan materi perbandingan dan adanya hubungan kovarisional antara lama panen dan hasil panen dengan luas lahan. Namun S2 keliru memahami bahwa menghitung lama panen juga merupakan masalah proporsional.

Untuk menggali lebih dalam profil penalaran S2 dalam memecahkan masalah yang diberikan, berkut cuplikan wawancara dengan S2.

P: Menurut kamu, soal seperti ini berkaitan dengan materi apa?

$S_{1}$ : Materi perbandingan kak.

$P$ :Apakah kedua pertanyaan dari soal ini berkaitan dengan materi perbandingan?

S1 : lya kak.

$P$ : Apa alasanmu mengatakan demikian?

S1: Karena diketahui luas kebun dari dua orang petani jagung dan lama panen salah satu petani, dan hasil panen salah satu petani. Kemudian ditanyakan lama panen dan hasil panennya. Untuk mencari lama panen dan hasil panen dapat dibuat perbandingannya kak.

$P$ : Mengapa untuk menentukan lama panen dan hasil panen dapat menggunakan perbandingan?

$S_{1}$ : Karena lama panen dan hasil panen sebanding dengan luas kebun. Semakin luas kebun maka semakin banyak dan lama pula panenya. Begitu juga sebaliknya kak.

\section{PEMBAHASAN}

Berikut ini akan dipaparkan profil penalaran proporsional subjek bergaya kognitif sistemtis dan subjek bergaya kognitif intuitif dalam memecahkan masalah terkait materi perbandingan.

\section{Profil Penalaran Proporsional Subjek Bergaya Kognitif Sistematis dalam Memecahkan Ma- salah Matematika}

Berikut akan dipaparkan penlaran prporsional subjek bergaya kognitif sistematis berdasarkan tahap pemecahan masalah yang dikemukakan oleh Polya (1973).

Pada tahap memahami masalah, subjek bergaya kognitif sistematis mengetahui den- 
gan baik informasi yang diberikan pada soal yang akan diselesaikan. Namun, subjek bergaya kognitif sistematis melakukan kesalahan dalam menggolongkan masalah yang akan diselesaikan apakah termasuk masalah proporsional atau non-proporsional. Subjek bergaya kognitif sistematis menjelaskan bahwa masalah yang diberikan merupakan masalah proporsional karena dua kuantitas pada masalah yang diberikan memiliki hubungan kovariasional. Padahal terdapat satu kuantitas yang tidak dipengaruhi oleh kuantitas yang lain.

Pada tahap menyusun rencana, subjek bergaya kognitif sistematis menjelaskan rencana penggunaan kuantitas dengan mengelompokkan bagian-bagian yang diketahui terlebih dahulu. Hal ini dilakukan untuk memudahkan menentukan nilai-nilai kuantitas yang sebanding atau memiliki hubungan kovariasional. Selain itu, subjek bergaya kognitif sistematis menjelaskan rencana penggunaan kuantitaskuantitas tersebut dengan menyusun persamaan yang akan digunakan dalam menyelesaikan masalah yang diberikan.

Pada tahap melaksanakan rencana, subjek bergaya kognitif sistematis membuat proporsi antar kuantitas dan membuat persamaan berdasarkan rasio antar dua kuantitas. Hal ini memungkinkan dilakukan karena menurut subjek bergaya kognitif sistematis perbandingan antara dua kuantitas tersebut merupakan perbandingan senilai. Dalam menyelesaikan persamaan, subjek bergaya kognitif sistematis cenderung menggunakan cross product algorithm strategy. Cross product algorithm strategy merupakan strategi dimana subjek menyusun proporsi ke dalam bentuk , kemudian melakukan perkalian silang untuk menentukan nilai yang tidak diketahui (Avcu \& Avcu, 2010). Cross product algorithm strategy memang sangat sesuai dengan tipe orang yang bergaya kognitif sistematis. Sebagaimana yang dipaparkan Jena (2010) bahwa orang bergaya kognitif sistematis memiliki kecenderungan untuk berpikir logis dan menggunakan pendekatan dengan langkah-langkah yang terdefinisi dengan jelas, maka cross product algorithm strategy merupakan strategi dengan langkah-langkah yang terukur dan terdefini dengan sangat jelas. Bahkan pada soal menghitung lama panen yang sebenarnya merupakan masalah non-proporsional (konstan), subjek sistematis juga menggunakan cross product algorithm strategy. Selanjutnya apabila ada bagian yang belum diketahui dari perbandingan yang akan dibentuk, maka subjek bergaya kognitif sistematis terlebih dahulu menentukan bagian tersebut. Selain itu, subjek bergaya kognitif sistematis memiliki pemahaman yang baik terkait kovariasional. Hal ini terlihat dari keluwesan subjek dalam membentuk persamaan yang digunakan dalam menyelesaikan soal. Subjek bergaya kognitif sistematis memahami pecahan sebagai bagian dari keseluruhan dan menggunakannya dalam menentukan nilai kuantitas lain yang mempengaruhi nilai kuantitas yang ditanyakan.

Pada tahap memeriksa kembali, subjek bergaya kognitif sistematis dalam memeriksa kembali hasil pekerjaannya menggunakan dua cara. Cara pertama ialah dengan melihat kesesuaian solusi yang diperoleh dengan masalah yang diberikan. Cara kedua dengan melihat nilai perbandingan yang diperoleh dari persamaan. Cara kedua ini memungkinkan karena menurut subjek bergaya kognitif sistematis jika perbandingan yang diperoleh sama dengan perbandingan yang diketahui maka jawaban yang diperoleh benar.

\section{Profil Penalaran Proporsional Subjek Bergaya Kognitif Intuitif dalam Memecahkan Masalah Matematika}

Berikut akan dipaparkan penlaran prporsional subjek bergaya kognitif intuitif berdasarkan tahap pemecahan masalah yang dikemukakan oleh Polya (1973).

Pada tahap memahami masalah, subjek bergaya kognitif intutif mengetahui dengan baik informasi yang diberikan pada soal dan masalah yang akan diselesaikan. Namun subjek melakukan kesalahan dalam menggolongkan masalah yang akan diselesaikan apakah termasuk masalah proporsional dan masalah non-proporsional. Subjek bergaya kognitif intutif menjelaskan bahwa masalah yang diberikan merupakan masalah proporsional karena dua kuantitas pada masalah yang diberikan memiliki hubungan kovariasional. Padahal terdapat satu kuantitas yang tidak dipengaruhi oleh kuantitas yang lain. 
Pada tahap menyusun rencana, subjek bergaya kognitif intutif menggunakan kuantits yang diketahui dengan membuat perbandingan antara dua kuantitas yang diketahui. Hal ini dilakukan karena menurut subjek bergaya kognitif intutif, membuat perbandingan dinilai paling efektif untuk menjawab masalah yang diberikan. Selain itu, subjek bergaya kognitif intutif juga menjelaskan rencana penggunaan perbandingan tersebut dengan menyusun persamaan yang akan digunakan dalam menyelesaikan masalah yang diberikan.

Pada tahap melaksanakan rencana, subjek bergaya kognitif intutif cenderung menggunakan strategi build-up method dan factor of change strategy, untuk memperoleh solusi, dari masalah yang diberikan. Build-up method merupakan strategi memperbesar atau memperkecil rasio, kemudian menjumlahkannya dalam rangka mencari solusi (Avcu \& Avcu, 2010). Sedangkan, Strategi factor of change merupakan strategi dimana perubahan rasio sebesar $m$ kali, akan mengakibatkan perubahan pada kuantitas yang lain dengan rasio yang sama (Avcu \& Avcu, 2010). Kedua strategi ini digunakan oleh subjek bergaya kognitif intutif karena menurut subjek tersebut menyederhanakan perbandingan tidak mengubah hasil dan memudahkan perhitungan. Selain itu, Strategi build-up method ataupun factor of change merupakan strategi yang sangat cocok bagi seseorang yang bergaya kognitif intuitif. Sebagaimana yang dipaparkan oleh Martin (1998) bahwa seseorang dengan gaya kognitif intuitif cenderung berpikir secara spontan, berdasarkan intuisi, tidak menggunakan metode yang jelas, serta menggunakan pola penalaran induktif. Subjek bergaya kognitif intuitif juga memiliki pemahaman kovariasional yang baik, sehingga dapat dengan tepat memilih perbandingan yang akan digunakan dalam menjawab soal. Selain itu, subjek bergaya kognitif intutif juga memiliki pemahaman terhadap rasio yang baik serta memahami pecahan sebagai rasio, sehingga ia dapat memanipulasi rasio sesuai dengan kebutuhannya dalam menyelesaikan soal. Dalam menyelesaikan masalah yang diberikan, subjek bergaya kognitif intuitif juga mengembangkan strategi unik dalam menyelesaikan masalah yang diberikan yaitu membuat perbandingan dari kuantitas yang ditanyakan dengan memanfaatkan perbandingan yang diketahui lalu dikurangkan dengan rasio dari suatu kuantitas yang berhubungan dengan kuantitas yang ditanyakan. Hal ini memungkinkan subjek bergaya kognitif intuitif memperluas hubungan kuantitas yang sama ke pasagan kuantitas baru yang diperoleh.

Pada tahap memeriksa kembali, subjek bergaya kognitif intuitif dalam memeriksa kembali hasil jawaban yang dibuat. Subjek bergaya kognitif intuitif cenderung melihat kesesuaian solusi yang diperoleh dengan masalah yang diberikan. Selain itu, Subjek bergaya kognitif intuitif juga melihat nilai perbandingan yang diperoleh dari persamaan. Hal ini memungkinkan dilakukan karena menurut subjek bergaya kognitif intuitif jawaban yang diperoleh benar jika perbandingan yang diperoleh sama dengan perbandingan yang diketahui.

Berdasarkan profil penalaran pada masing-masing subjek, terlihat bahwa secara umum subjek bergaya kognitif sistematis dan intuitif pada tahap memahami masalah mengalami kegagalan dalam membedakan masalah proporsional dan bukan proporsional. Selain itu, kedua subjek juga memiliki kesamaan dalam memeriksa kembali hasil pekerjaannya yaitu dengan melihat kesesuaian solusi dan melihat nilai perbandingan yang diperoleh.

Selain menunjukkan beberapa kesamaan terkait penalaran proporsional dalam memecahkan masalah matematika, kedua subjek juga menunjukkan beberapa keunikan profil penalaran proporsional masing-masing subjek dalam memecahkan masalah. pada tahap merencanakan, subjek bergaya kognitif sistematis cenderung mengelompokkan kuantitas-kuantitas yang diketahui terlebih dahulu, kemudian menyusun persamaan yang akan digunakan dalam menyelesaikan masalah yang diberikan. Sedangkan subjek bergaya kognitif intuitif cenderung membuat perbandingan antara dua kuantitas yang diketahui, kemudian menyusun peramaan dari perbandingan yang diperoleh untuk menyelesaikan masalah yang diberikan.

Pada tahap melaksanakan rencana, subjek bergaya kognitif sistematis cenderung 
membuat proporsi antar kuantitas dan membuat persamaan berdasarkan rasio antar dua kuantitas. Selain itu, subjek bergaya kognitif sistematis dalam menyelesaikannya menggunakan strategi cross product algorithm. Sedangkan subjek bergaya kognitif intuitif cenderung menggunakan strategi build-up method dan factor of change untuk memperoleh solusi dari masalah yang diberikan. Selain itu, subjek bergaya kognitif intuitif juga mengembangkan strategi unik dalam meyelesaikan masalah yang diberikan yatu membuat perbandingan dari kuantitas yang ditanyakan dengan memanfaatkan perbandingan yang diketahui dan dikurangkan dengan rasio dari suatu kuantitas yang berhubungan dengan kuantitas yang ditanyakan.

Selain memiliki persamaaan dan perbedaan, dalam memecahkan masalah matematika yang diberikan kedua subjek memiliki keunggulan masing-masing. Namun demikian, tidak ada yang lebih baik diantara keduanya. Subjek bergaya kognitif sistematis memiliki keunggulan yaitu subjek memecahkan masalah yang diberikan lebih runtut sehingga memudahkan orang lain yang membaca hasil pekerjaannya meski tanpa melalui wawancara. Sedangkan subjek bergaya kognitif intuitif memiliki keunggulan yaitu subjek cenderung lebih cepat dalam menyelesaikan masalah yang diberikan, karena subjek cenderung memandang masalah secara global kemudian menyusun rencana untuk menyelesikannya.

Selain memiliki keunggulan-keunggulan, kedua subjek memiliki kelemahan masing-masing. Subjek bergaya kognitif sistematis memiliki kelemahan yaitu subjek cenderung mempartisi masalah yang diberikan menjadi beberapa bagian sehingga subjek lebih lambat dalam menyelesaikan masalah. Sedangkan subjek bergaya kognitif intuitif memiliki kelemahan yaitu alur berpikir subjek sulit dipahami jika hanya melihat dari hasil pekerjannya, sehingga perlu dilakukan proses wawancara mendalam untuk mengetahui alur berpikir subjek dengan baik.

\section{PENUTUP}

\section{Simpulan}

Berdasarkan hasil penelitian menunjukkan bahwa kedua subjek gagal membedakan masalah proporsional dan bukan proporsional pada tahap memahami masalah. Pada tahap menyusun rencana, Siswa bergaya kognitif sistematis mengelompokkan bagian-bagian yang sebanding untuk membuat persamaan. Sedangkan siswa bergaya kognitif intuitif membandingkan kuantitas-kuantitas yang diketahui, kemudian menyederhanakan perbandingannya. Pada tahap melaksanakan rencana, siswa bergaya kognitif sistematis menggunakan strategi cross product algorithm untuk menemukan solusi. Sedangkan siswa bergaya kognitif intuitif menggunakan strategi build-up method dan factor of change untuk menemukan solusi. Pada tahap memeriksa kembali, Siswa bergaya konitif sistematis dan intuitif mengecek solusi yang mereka peroleh dengan mensubtitusi masing-masing solusi ke persamaan, kemudian melihat nilai perbandingan yang dihasilkan. Jawaban benar jika nilai perbandingan dalam persaamaan tersebut sama.

\section{Saran}

Bagi peneliti lain yang tertarik mengkaji mengenai penalaran proporsional siswa dalam memecahkan masalah, diharapkan dapat menggunakan masalah sehari-hari terkait konsep perbandingan berbalik nilai. Selain itu, diharapkan penelitian selanjutnya dapat mengakomodasi perbedaan kemampuan matematika pada saat melakukan penelitian.

\section{DAFTAR PUSTAKA}

Avcu, R. \& Avcu, S. (2010). $6^{\text {th }}$ Grade Students Use of Different Strategies in Solving Ratio Proportion Problems. Procedia Social and Behavioral Sciences, 9: 1277-1281.

Ben-Chaim, David, Keret Y., \& llany B.S. (2012). Ratio and Proportion: Research and Teaching in Mathematics Teachers'Education.

Dole, S., Clarke, D., Wright, T., \& Hilton, G.(2012). Students' Proportional Reasoning in Mathematics and Science. Dalam Tso, T.Y.(ED), Proceedingsof the $36^{\text {th }}$ Conference of The International Group for the Psychology of Mathematics Education, 2, 195202.

Frith, V. \& Llyod, P. (2016). Proportional Reasoning Ability of School Leavers Aspiring to Higher Education in South Africa. Pythagoras - Journal of the Association for Mathematics Education of South Africa. 1-10.

Jena, P. Chandra. (2014). Cognitive Styles and Problem Solving Ability of Under Graduate Students. In- 
170 Akhmad Faisal Hidayat dkk, Profil Penalaran Proporsional Siswa SMP dalam Memecahkan Masalah

ternational Journal of Educationand Psychological Research (IJEPR), 3(2), 71-76.

Keen, P. G. W. (1974). Cognitive Style and The Problem Solving Process: An Experiment.

Lamon, S. J. (2007). Rasional Numbers and Proportional Reasoning: Towards a Theoretical Framework for Research. In F. K. Lester (Ed.), Second Handbook of Research on Mathematics Teaching and Learning (pp. 629-667). Charlotte, NC: Information Age Publishing.

Lamon, S. J. (2012). Teaching Fractions and Ratios for Understanding: Essential Content Knowledge and Instructional Strategies for Teachers ( $3^{\text {rd }}$ Edition). New York : Routledge.

Lesh, R., Post, T., \& Behr, M. (1988). Proportional Reasoning. In J. Hiebert \& M. Behr (Eds.) Number Concepts and Operations in the Middle Grades,
93-118. Reston, VA: Lawrence Erlbaum \& National Council of Teachers of Mathematics.

Martin, L. P. (1998). The Cognitive Style Inventory. The Pfeiffer Library, volume 8, $2^{\text {nd }}$ Edition.

National Council of Teacher of Mathematics. (2000). Principles and Standards for School Mathematics. Washington D. C.: National Academi Press.

Permendikbud. (2014). Kurikulum 2013 Sekolah Menengah Pertama/Madrasah Tsanawiyah. Kementrian Pendidikan dan Kebudayaan Republik Indonesia.

Polya, G. (1973). How to Solve It: A new aspect of mathematical method. New Jersey: Priceton University Press.

Walle, J. A. (2013). Elementary and Middle School Mathematics: Teaching Develo 'pmentally, eighth Edition. 